\title{
Selective agglutination of tourmaline grains by foraminifera in a deep-water flysch environment (Eocene Hieroglyphic Beds, Silesian Nappe, Polish Outer Carpathians)
}

\author{
Anna WAŚKOWSKA ${ }^{1, *}$ \\ 1 AGH University of Science and Technology, Faculty of Geology, Geophysics and Environmental Protection, \\ Al. A. Mickiewicza 30, 30-059 Kraków, Poland
}

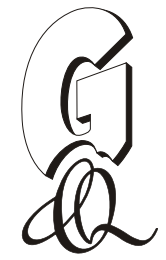

\begin{abstract}
Waśkowska, A., 2014. Selective agglutination of tourmaline grains by foraminifera in a deep-water flysch environment (Eocene Hieroglyphic Beds, Silesian Nappe, Polish Outer Carpathians). Geological Quarterly, 58 (2): 337-352, doi: 10.7306/gq.1154

Detrital fragments of automorphic tourmaline crystals are commonly incorporated into the tests of simple agglutinated foraminifera that lived in the deep-marine Carpathian turbidite basin in which the deposition of the Hieroglyphic Beds (Eocene) took place. Such grains were observed in the tests of 37 species representing 20 genera. In spite of the fact that tourmaline occurs in the Carpathian Flysch sediments as an accessory mineral, still it was selected by the foraminifera as the only heavy mineral to be incorporated into their tests. The proportion of tourmaline-bearing specimens in an assemblage usually amounts to a few percent, but may reach $29 \%$ in extreme cases. The particular preference for tourmaline selection and incorporation in the test walls is shown by the following genera: Psammosiphonella, Reophax, Bathysiphon and Nothia.
\end{abstract}

Key words: heavy minerals, tourmaline, agglutinated foraminifera, deep-marine flysch environment, Outer Carpathians.

\section{INTRODUCTION}

Agglutinated foraminifera are among the most widespread meiofaunal organisms in marine basins. Most of them are considered as cosmopolitan organisms, well-adapted to environments ranging from shelf to deep-marine, and tolerant to high hydrostatic pressure, salinity and temperature (e.g., Łuczkowska, 1993; Kaminski and Gradstein, 2005 and references therein). The characteristic feature of these organisms is the mode of formation of their tests, which consists of allogenic grains bound together with organic or calcareous cement secreted by the organism (e.g., Murray, 1973; Łuczkowska, 1993; Bender and Hemleben, 1988; Hemleben and Kaminski, 1991; Podobina and Tatyanin, 2000 and references therein). The grains that comprise such tests are derived from the sediment covering the basin floor surface, or from a thin zone underneath. Quartz grains constitute the most common detrital component, but there are also tests composed, partly or entirely, of organic material, i.e. coccolihts, sponge spicules, tests of other foraminifera, diatoms, radiolarians, or fine fragments of bivalve tests (Smith and Kaesler, 1970; Tendal et al., 1982; Commeau et al., 1985; Cartwright et al., 1989; Gooday and Claugher, 1989; Gooday et al., 1995a, 2002, 2010; Allen et al., 1999; Gooday and Smart, 2000; Thomsen and Rasmussen, 2008 and references therein). Besides quartz, the following inorganic

\footnotetext{
*E-mail: waskowsk@agh.edu.pl
}

Received: March 1, 2014; accepted: March 10, 2014; first published online: March 11, 2014 detrital components are observed in the foraminifera test walls: calcite, aragonite, dolomite, glauconite, feldspars, micas, pyroxene, hornblende, magnetite, pyrite as well as other heavy minerals, e.g. topaz, ilmenite, magnetite, rutile, zircon, minerals representing the garnet group, apatite, amhibole, and phillipsite (e.g., Heron-Allen, 1915; Switzer and Boucot, 1955; Weston, 1984; Höfling, 1988; Gooday et al., 1995b; Bartholdy et al., 2005; Makled and Langer, 2009; Mancin et al., 2012 and citations therine). Also shocked diamond grains (Kaminski et al., 2008) and volcanic glass fragments (Switzer and Boucot, 1955; Hess et al., 2000) were sporadically observed among the agglutinated grains. Recent research shows that some of the agglutinated foraminifera assemblages that lived in the Carpathian flysch basin ca. 35 million years ago used tourmaline grains, in addition to quartz, feldspar, and muscovite, as a common detrital component of their tests (Waśkowska and Łodziński, 2011a, b). Therefore, the aims of this paper are to present detailed observations focused on tourmaline-agglutinating foraminifera from the Outer Carpathian basin, and discuss their occurrences from a more general perspective of deep-marine foraminiferal assemblages of this region.

\section{STUDY AREA AND LITHOSTRATIGRAPHY}

This study pertains to the Polish sector of the Outer Carpathians (Fig. 1). The depositional successions of the Outer Carpathians consist mainly of deep-marine flysch sequences deposited in the western part of the Tethys Ocean, known as the Carpathian Basin (e.g., Książkiewicz, 1962, 1977; Ślączka and Kaminski, 1998, Golonka et al., 2006, 2008, 2013; Ślączka 

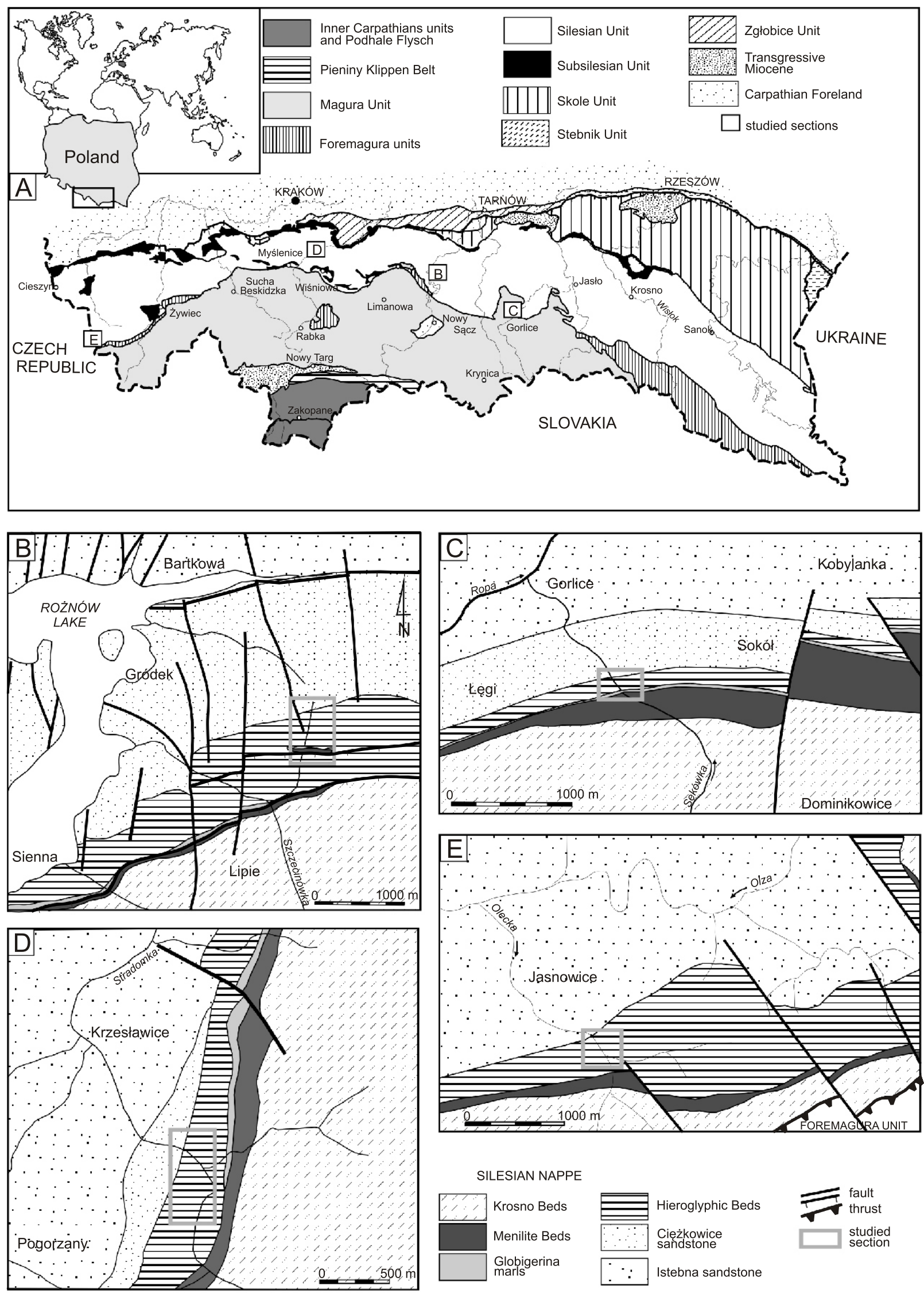

Fig. 1. Location of study area

A - tectonic sketch-map of Polish Carpathians (map after Żytko et al., 1989, modified); B-D - geological maps of the studied sections: B Gródek area, location of Lipie section (map after Cieszkowski, 1992, modified), C - Gorlice area, location of the Sękówska section (map after Szymakowska, 1979, modified), D - Krzesławice area, location of the Stradomka section (map after Burtan, 1974, modified), E - Jasnovice area, location of the Olecka section (map after Burtan, 1972, modified) 


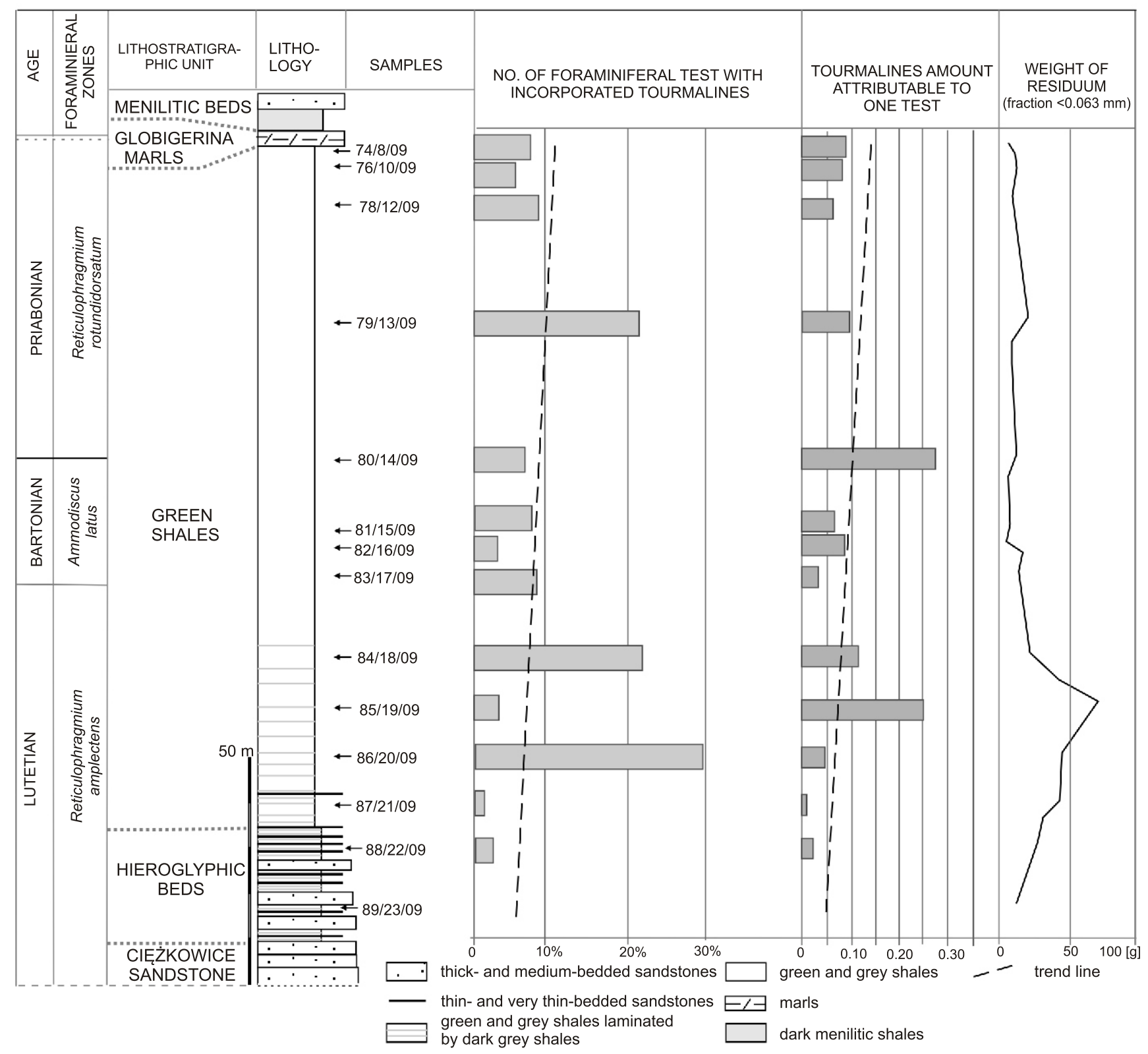

Fig. 2. Distribution of tourmaline amount along lithological log of the Lipie section

et al., 2006; Golonka and Waśkowska-Oliwa, 2007 and references therein). The Carpathian Basin existed and evolved from the Jurassic to the Miocene times. Elevated ridges separated it into sub-basins, and their configuration and numbers varied with time. One of these depositories was the Silesian Basin (e.g., Książkiewicz, 1972; Unrug, 1979; Cieszkowski 1992; Golonka and Waśkowska-Oliwa, 2007; Golonka et al., 2013 and references therein; Fig. 1). The peak of the orogenic movements occurred in the Miocene and resulted in folding, thrusting and uplift of the basinal sedimentary successions (Książkiewicz, 1962, 1977; Cieszkowski, 1992; Golonka and Waśkowska, 2007; Golonka et al., 2013). As a result, the Outer Carpathians consist of a sequence of nappes thrust towards the north, which contain deep marine deposits of the former Carpathian Basins (Fig. 1).

The Silesian Nappe, which hosts the lithostratigraphic unit of the Hieroglyphic Beds (Eocene) investigated in this project, occupies the central part of the Polish Flysch Carpathians, and is bordered by other nappes to the south (Fig. 1). The occurrences of the Hieroglyphic Beds and the Green Shales (Figs. 2 and 3 ) in the western part of the Silesian Nappe were sampled at the following localities (Fig. 1): the region of Istebna (Olecka section), Szczyrzyc (Stradomka section), Rożnów Lake (Lipe section) and Gorlice (Sękówka section; Fig. 1).

The Hieroglyphic Beds are a succession of thin-bedded shaly-sandy turbidites. The predominant facies of grey or greenish-grey non-calcareous shales are intercalated with thinor medium-bedded fine-grained quartz arenites, mainly parallel or ripple cross-laminated and grey in colour. Numerous bio- and mechanoglyphs observed on soles of sandstone beds are characteristic for this unit. Simultaneously, the accompanying mudstones are commonly bioturbated. Variegated and green mudstones are locally present as intercalations. A horizon of green mudstones, marly in the uppermost part of the succession, occurs as an informal subdivision succeeding the Hieroglyphic Beds. The lower boundary of the Hieroglyphic Beds is 
STRADOMKA SECTION



\section{OLECKA SECTION}
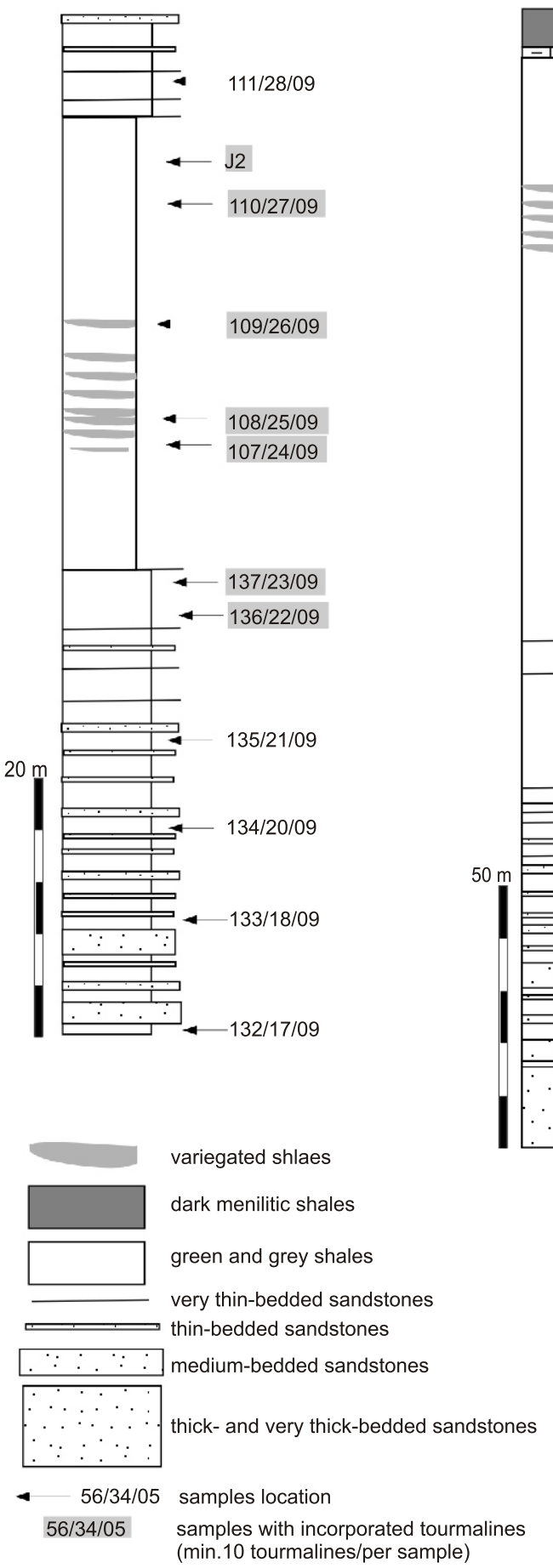

\section{SĘKÓWKA SECTION}



Fig. 3. Distribution of foraminiferal samples with tourmaline along lithological logs of the Hieroglyphic Beds in the Jasnovice, Krzesławice and Gorlice areas

regionally diachronous and marked by the basal contact with different lithostratigraphic units. Namely, in the western and central sectors of the Polish Outer Carpathians (Olecka and Stradomka sections analysed in this study) the age of the Hieroglyphic Beds ranges from the Early to Late Eocene (Burtan et al., 1956; Burtan, 1974, 1978; Chodyń and WaśkowskaOliwa, 2006). However, in the western region (Lipie and Sękówka sections) the Hieroglyphic Beds appear later - in the
Middle Eocene - and are underlain by the thick-bedded Ciężkowice Sandstone Formation, which forms a wedge between the Istebna Beds below and the Hieroglyphic Beds above (Szymakowska, 1979; Cieszkowski et al., 1991; Cieszkowski, 1992; Leszczyński and Radomski, 1994). In the Silesian Nappe section at Rożnów Lake (Lipie section), the green mudstone unit locally replaces the Hieroglyphic Beds, and is mainly Late Eocene, rarely Middle-Late Eocene in age. 


\section{METHODS AND ANALYTICAL MATERIAL}

The samples collected for micropalaeontological analysis represent mudstones of the Hieroglyphic Beds and the overlying Green Shales from the Silesian Nappe (Figs. 1-3). 67 samples were analysed, out of which 35 contained tourmaline-bearing foraminiferal tests.

For each sample, about $0.5 \mathrm{~kg}$ of the rock was processed following standard micropalaeontological procedure. After maceration in an aqueous solution of Glauber's salt $\left(\mathrm{NaSO}_{4}\right)$, the material was washed on $0.068 \mathrm{~mm}$ mesh size sieve. Foraminiferal tests were hand-separated from the residue retained on the sieve and taxonomically verified. Subsequently, tourmaline-bearing tests were separated for further study. This involved observations under low-magnification binocular microscope Nikon VL100POL and with a scanning electron microscope FEI QUANTA 200 FEG. Electron microprobe analyses (EMPA) of selected specimens were conducted with a CAMECA SX 100 Electron Microprobe in wavelength-dispersive spectrometry (WDS) mode at the Inter-Institute Analytical Complex for Minerals and Synthetic Substances, Warsaw.

A complete documentation of this work, including the collection of forminiferal tests, is housed with the author at $A G H$, Kraków.

\section{RESULTS}

MINERAL COMPOSITION OF AGGLUTINATED FORAMINIFERAL TESTS

The foraminiferal assemblages identified in the analysed samples are dominated by agglutinated taxa. The tests of most specimens consist of quartz grains only, which are usually angular to subangular in shape and varying in size (Figs. 4 and 5). Some specimens, especially with coarse-grained tests (Reohax, Bathysiphon), also contain feldspar grains and biogenic particles, i.e., solitary coccoliths, diatoms, siliceous sponge spicules occur in the tests of Bathysiphon. Muscovite flakes were found in tests from the Lower Eocene Hieroglyphic Beds in the Janoska section. Solitary tourmaline grains were observed in some specimens, and authigenic pyrite occurs in the analysed tests as a diagenetic component.

Tourmaline grains incorporated in the foraminiferal tests can be identified relatively easily under a low-magnification microscope. They are a contrasting and accessory component of tests typically composed of quartz grains (Fig. 6). Quartz grains appear grey in colour with a greasy lustre; their shape is usually irregular reflecting the lack of cleavage, and show a viariable degree of roundness. In contrast, tourmaline grains usually show glassy lustre, are angular to subangular, and have an elongated regular shape reflecting the original idiomorphic crystal form. Fragmented tourmaline crystals are split along the cleavage surfaces, thus retaining in the characteristic columnar shape of the parent mineral, or are broken perpendicularly to the column axis. They have a distinct vitreous lustre, display characteristic colour usually markedly darker than other detrital components of the test and are often much coarser-grained than quartz - a feature that attracts the observer's attention in addition to other characteristics.

FEATURES OF TOURMALINE GRAINS

Form of tourmaline grains. The tourmaline grains incorporated in the foraminiferal tests represent automorphic crystalline columnar forms (Figs. 4-6) that are usually abraded very lit- tle. Most often they occur as crystals broken perpendicularly to the long axis, but very fine crystals remain intact (Figs. 4-6). There are also grains resulting from disintegration along the crystal axis, following the indistinct cleavage surfaces (Żaba, 2003). Longitudinal striations, characteristically parallel to the long axis, can be seen clearly on the surface of many tourmaline grains. Both outer crystal faces and cleavage surfaces show features resulting from corrosion (Figs. 4-6).

Chemical composition of tourmalines. Considering their optical properties, two types of tourmaline grains can be discerned under transmitted light microscope. Type one is represented by grains light brown to yellowish-brown, or yellowish-green in colour, mainly transparent and semi-transparent with pleochlorism. Grains that are opaque and black in colour represent the second type and occur less frequently than grains of the first type.

Semi-quantitative analyses reveal at least two kinds of tourmaline assemblages in terms of chemical composition, i.e. the content of the main elements $(\mathrm{Al}, \mathrm{Mg}, \mathrm{Fe})$ and trace elements $(\mathrm{Na}, \mathrm{Ti}, \mathrm{K})$. Members rich in $\mathrm{Mg}-\mathrm{NaMg}_{3} \mathrm{Al}_{6}\left(\mathrm{BO}_{3}\right)_{3} \mathrm{Si}_{6} \mathrm{O}_{18}(\mathrm{OH})_{4}$ (dravite; Fig. 7) and rich in $\mathrm{Fe}^{2+}-\mathrm{NaFe}^{2+}{ }_{3} \mathrm{Al}_{6}\left(\mathrm{BO}_{3}\right)_{3} \mathrm{Si}_{6} \mathrm{O}_{18}(\mathrm{OH})_{4}$ (schorl) were identified. Al- and Li-dominant members $\mathrm{Na}(\mathrm{Al}, \mathrm{Li})_{3} \mathrm{Al}_{6}\left(\mathrm{BO}_{3}\right)_{3} \mathrm{Si}_{6} \mathrm{O}_{18}(\mathrm{OH})_{4}$ (elbaite) were not observed (Waśkowska and Łodziński, 2011a, b). Quantitatively, dravite grains of varying $\mathrm{Fe} / \mathrm{Mg}$ proportions predominate significantly over schorl, the occurrences of which are rare.

Size of tourmalines grains. The long axes and widths of tourmaline grains in foraminiferal tests from the Lipie section were measured under the scanning microscope (Table 1). In general, the grain size appears variable. More than half of the measured grains are 39-69 $\mu \mathrm{m}$ long, with the most common size range 50-59 $\mu \mathrm{m}$ (Fig. 8). This is in agreement with average axis length, which amounts to $57.5 \times 23.5 \mu \mathrm{m}$ for the analysed sample. As to the width measurements, grains $10-20 \mu \mathrm{m}$ wide predominate; $2 / 3$ of the measured tourmaline grains fall in the $10-30 \mu \mathrm{m}$ range. The largest of the observed grains, $166.5 \mu \mathrm{m}$ long and $111 \mu \mathrm{m}$ wide, was found in a specimen of Reophax in a sample from the Sękówka section (Fig. 6). The size of the finest grain amounts to $13 \times 3 \mu \mathrm{m}$ (Table 1 ); however, it must be noted that grains of extreme dimensions occur very rarely.

Long crystals of various lengths represent tourmaline grains of columnar shape. Most commonly, the ratio of length to width is in the range 4-5.5. However, the foraminifera tended to incorporate in their test fragments of tourmaline crystals that geometrically represent short or long column, with length-to-width ratio for most of the observed grains ranging from 1.5 to 3.5 (Figs. 4-6, Table 1).

Tourmaline grains are found incorporated into foraminiferal tests of various sizes. However, most commonly they occur in coarse-grained tests in which the average size of quartz grains, which constitute the fundamental building material, exceeds $40 \mu \mathrm{m}$. Such coarse-grained tests observed in the analysed samples belong to species of Reophax, Psammosiphonella, Recurvoides and Karrerulina. The coarsest tourmaline grains are incorporated into the tests of Reophax duplex Grzybowski, $R$. pilulifer Brady, Pseudonodosinella elongata (Grzybowski) and Psammosiphonella cylindrica (Glaessner). Finer, medium silt, tourmaline grains occur in tests composed of generally fine and very fine detritus (medium - very fine silt), e.g. in Paratrochamminoides and Trochamminoides div. sp., Ammodiscus peruvianus Berry, Trochammina umiatensis Tappan, Haplophragmoides walteri (Grzybowski) and Reticulophragmium amplectens (Grzybowski).

Frequency and numbers of tourmaline grains in foraminiferal tests. Tourmaline grains are usually solitary and isolated components that occur as one to four crystals in a single agglutinated foraminiferal test (Figs. 4 and 5). Most of the 




Fig. 4. SEM images of foraminifera with tourmaline casts

A - Psammosiphonella cylindrica (Glaessner) (sample 76/10/09), B - Trochammina sp. (84/19/09), C - chamber from Reophax sp. (81/15/09), D - Psammosiphonella cylindrica (Glaessner) (81/15/09), E - Bathysiphon sp. (75/5/98), F - Reophax duplex Grzybowski (68/2/09), G - Pseudonodosinella elongata (Grzybowski) (82/16/09), H - Paratrochamminoides sp. (68/2/09); scale bar - $50 \mu \mathrm{m}$ 


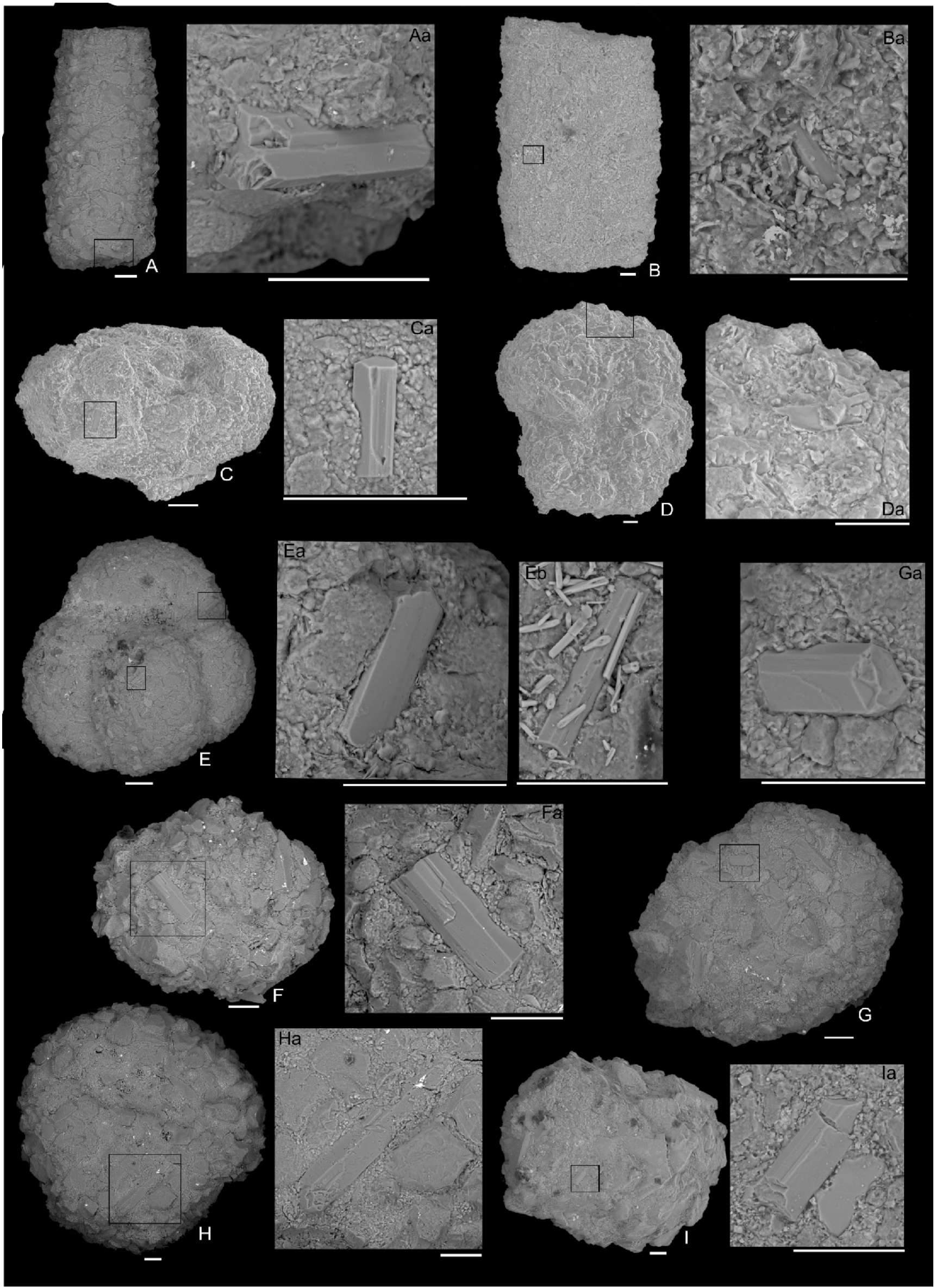

Fig. 5. SEM images of foraminifera with tourmaline casts

A - Psammosiphonella cylindrica (Glaessner) (sample 89/15/09), B - Bathysiphon sp. (43/47/06), C - Paratrochamminodes sp. (73/7/09), D - Popovia beckmanni (Kaminski et Geroch) (Stradomka 43/47/06), E - Trochammina sp. (81/15/09), F - chambers from Reophax sp. (Lipie 81/15/09), G - chamber from Reophax sp. (27/25/10), H - chamber from Reophax sp. (84/18/09); scale bar - 50 um 


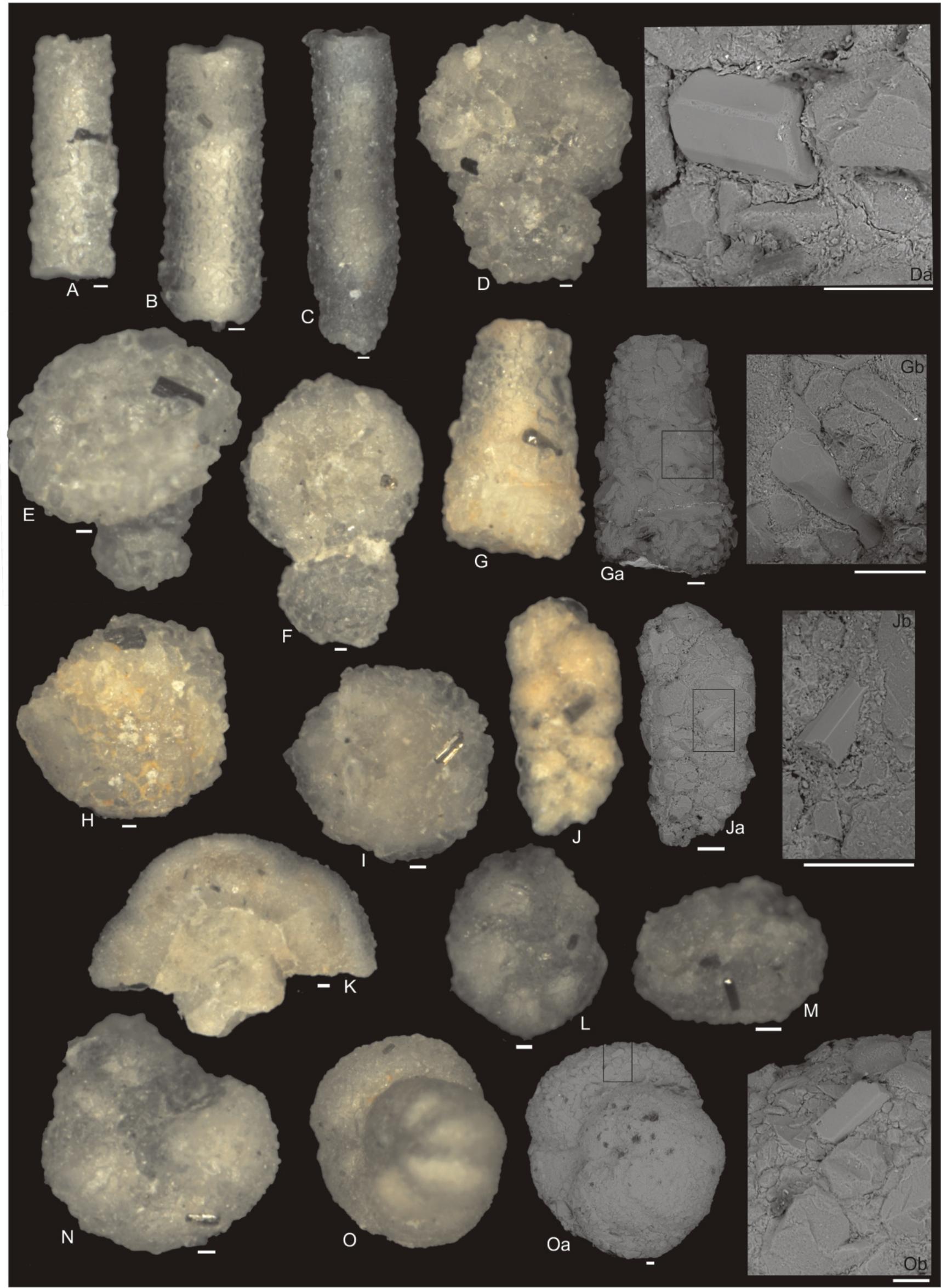

Fig. 6. Images of foraminifera with tourmaline casts

A - Psammosiphonella cylindrica (Glaessner) (sample 15/2/12), B - Psammosiphonella cylindrica (Glaessner) (80/13/09), C Psammosiphonella sp. (79/12/09), D, F - Reophax duplex Grzybowski (81/15/09), E - Reophax pilulifer Brady (15/2/12), G Pseudonodosinella elongata (Grzybowski) (82/16/09), H - chamber from Reophax sp. (78/12/09), I - chamber from Reophax sp. (71/5/09), J - Karrerulina sp. (124/3/09), K - Trochamminoides sp. (82/16/09), L, M, N - Recurvoides sp. (81/15/09), O - Cribrostomoides sp. (82/16/09); scale bar $-50 \mu \mathrm{m}$ 
A

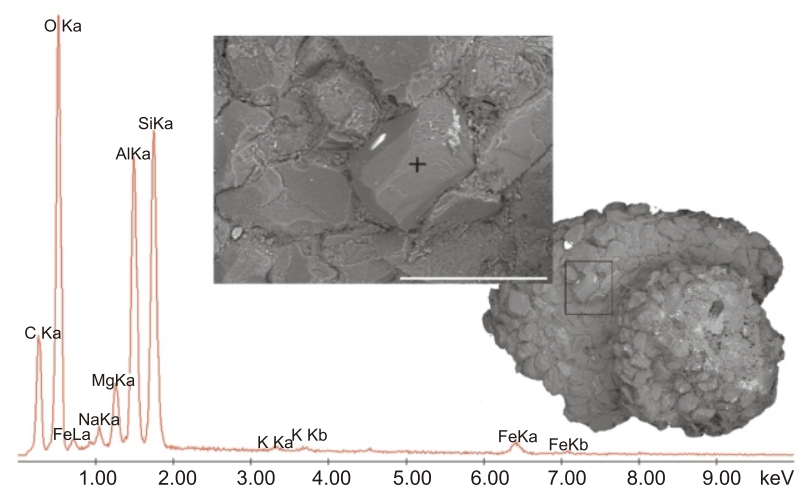

B

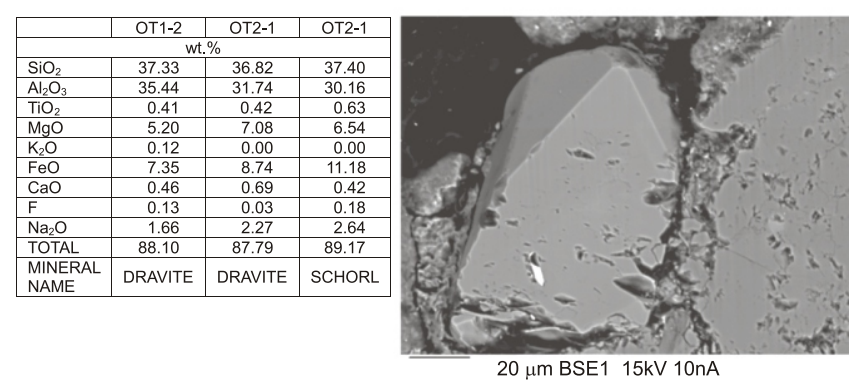

Fig. 7. Representative compositions of tourmaline (dravite) in the tests of agglutinated foraminifera

\section{A - EDS, B - WDS analyses}

analysed tests contain one tourmaline grain only, while three to four crystals per test appear very rarely. Torumaline grains are distributed randomly; sometimes they occur close to each other, but in other instances are widely separated. Their position within the test wall does not show any recurrent pattern: they occur along, across or obliquely relative to the chamber or test axis. However, the outer surface of the crystal is usually parallel to the outer surface of the test. In rare cases tourmaline columns are not oriented parallel to, but protrude above the curved test outline. These crystals are usually found as components of the outermost layer of the test, however, they occasionally occur incorporated within the inner structure of thick-walled tests, e.g., in Psammosiphonella cylindrica (Glaessner).

The numbers of the foraminifera with tourmaline grains incorporated in their tests vary from sample to sample. Individual samples contain from a few to several dozen of foraminiferal tests containing such grains, and the proportion of such foraminifera amounts to a maximum $2 \%$ of all foraminifera in the assemblage present in the sample. On the other hand, there are samples containing more tourmaline-bearing tests or lacking them completely.

The richest in tourmaline-bearing foraminifera is the Lipie section where almost all samples contain these grains (Fig. 2 and Appendix $\left.1^{*}\right)$. The quantity of such specimens is here exceptional and hardly comparable with the foraminiferal assemblages documented in other units of the Flysch Carpathians. In the discussed samples, the frequency ranges from $1 \%$ to over $29 \%$ of all specimens in the sample, and the estimated number of the incorporated individual tourmaline grains ranges from 8 to 1242 (Appendix 1). The average quantity of tourmaline

* Supplementary data associated with this article can be found, in the online version, at doi: $10.7306 / g q .1154$
T a ble 1

Sizes (in $\mu \mathrm{m}$ ) of tourmaline clasts in foraminiferal tests

\begin{tabular}{|c|c|c|}
\hline Lenght (a) & Widht (b) & $a / b$ \\
\hline 65.5 & 30.5 & 2.14 \\
\hline 52 & 13 & 4 \\
\hline 61 & 11 & 5.54 \\
\hline 50 & 22.5 & 2.22 \\
\hline 47.5 & 23.5 & 2.02 \\
\hline 30.5 & \begin{tabular}{|l|}
19.5 \\
\end{tabular} & 1.53 \\
\hline 50 & 30.5 & 1.63 \\
\hline 76 & 16.5 & 4.6 \\
\hline 61 & \begin{tabular}{|l|}
17.5 \\
\end{tabular} & 3.48 \\
\hline 80 & 26.5 & 3.01 \\
\hline 43.5 & 32.5 & 1.33 \\
\hline 50 & 25 & 2 \\
\hline 76 & 26 & 2.92 \\
\hline 52.5 & 30 & 1.73 \\
\hline 105.5 & 61 & 1.72 \\
\hline 41 & 12 & 3.41 \\
\hline 41 & 19 & 2.15 \\
\hline 100 & 53.5 & 1.86 \\
\hline 28.5 & 6.5 & 3.48 \\
\hline 46.5 & 20 & 2.32 \\
\hline 64.5 & 35 & 1.84 \\
\hline 35 & 11 & 3.18 \\
\hline 26.5 & 5 & 5.3 \\
\hline 36 & 20 & 1.8 \\
\hline 77 & 38.5 & 2 \\
\hline 61 & 17.5 & 3.48 \\
\hline 47.5 & 12 & 3.95 \\
\hline 45 & 18.5 & 2.43 \\
\hline 58.5 & 17.5 & 3.34 \\
\hline 54.5 & 13 & 4.19 \\
\hline 53 & 15.5 & 3.41 \\
\hline 33.5 & 13.5 & 2.48 \\
\hline 16.5 & 5.5 & 3 \\
\hline 18.5 & 7.5 & 2.46 \\
\hline 20 & 5 & 4 \\
\hline 50 & 20 & 2.5 \\
\hline 68.5 & 26.5 & 2.58 \\
\hline 31.5 & 11.5 & 2.73 \\
\hline 85.5 & 35.5 & 2.4 \\
\hline 55.5 & 20 & 2.77 \\
\hline 91.5 & 21 & 4.35 \\
\hline 13 & 3 & 4.33 \\
\hline 21.5 & 5 & 4.3 \\
\hline 23.5 & 7 & 3.35 \\
\hline 30.5 & 9 & 3.38 \\
\hline 45 & 15 & 3 \\
\hline 111 & 31 & 3.17 \\
\hline 53 & 26 & 2.03 \\
\hline 91 & 39 & 2.33 \\
\hline 68.5 & 18.5 & 3.7 \\
\hline 95.5 & 43.5 & 2.19 \\
\hline 80 & 30 & 2.66 \\
\hline 94.5 & 37 & 2.55 \\
\hline 166.5 & 111 & 1.5 \\
\hline 102.5 & 66 & 1.55 \\
\hline 60 & 12 & 5 \\
\hline 45 & 36 & 1.25 \\
\hline 53 & 21 & 2.52 \\
\hline 57 & 23 & 2.47 \\
\hline 50 & 22 & 2.27 \\
\hline
\end{tabular}






Fig. 8. Distribution of sizes of incorporated into foraminiferal tests tourmalines

grains per single test from Lipie varies from 0.1 and 0.27 crystals, with a mean of 0.09 (Fig. 2), while in Sękowka and Olecka sections the average value amounts to ca. 0.05 .

The distribution of the tourmaline-bearing foraminifera is not systematic in the analysed sections; however, there is a relationship between their presence (and quantity) and the lithology of the hosting sediment. In sections at Lipie, Stradomka and Sękówka such tests are either absent or alternatively attain the lowest of the values observed in the intervals of thin-bedded sandy-shaly turbidite sequences. But in shaly successions, devoid of sandstone interbeds, tourmaline grains constitute a common constituent of tests. Furthermore, their proportion increases parallel with the fining upwards trend of the hosting sedimentary facies evolving into mudstone-claystone associations. On the other hand, tourmaline-bearing foraminferal tests are a common occurrence in variegated shales.

Taxonomy of tourmaline-bearing forms. In samples from Lipie, tourmaline grains are incorporated in the tests of 37 species that represent 20 genera (Appendix 1). The tourmaline-bearing foraminifera usually belong to the assemblages of high diversity and rich in numbers, which thrived in ecologically favourable conditions.

The carriers of the highest proportion of tourmaline grains among all analysed samples are the species of Psammosiphonella, Reophax, Bathysiphon and Nothia. The tests of these forms concentrate the highest numbers of tourmaline grains; a part of these incorporates several crystals within a single test. Foraminifera that commonly include tourmaline grains in their tests are: Recurvoides, Trochamminoides - mainly $T$. subcoronatus (Grzybowski), T. grzybowskii Kaminski et Geroch, T. variolarius (Grzybowski), and Paratrochamminoides - mainly P. heteromorphus (Grzybowski), P. olszewskii (Grzybowski) and Trochammina (mainly Trochammina umiatensis Tappan; Appendix 1). Tests of the remaining taxa contain such grains only occasionally.

The frequency of occurrences of tourmaline-bearing tests within individual taxonomic groups is an interesting indicator (Table 2). Psammosiphonella and Rhabdammina contain tourmaline grains in a dozen to ca. $85 \%$, with the average quantity of $40 \%$ tests per sample. All analysed tests from Sękówka (sample no. 17/4/12) contained tourmaline grains, but this can-

Percentage of foraminiferal specimens with tourmalines within selected taxonomic groups

\begin{tabular}{|l|c|c|c|c|c|}
\hline \multicolumn{1}{|c|}{ Sample number } & $\begin{array}{c}\text { Bathysiphon } \\
\text { and Nothia }\end{array}$ & $\begin{array}{c}\text { Paratrochamminoides } \\
\text { and Trochamminoides }\end{array}$ & $\begin{array}{c}\text { Psammosiphonella } \\
\text { and Rhabdammina }\end{array}$ & Recurvoides & Reophax \\
\hline Lipe 88/22/09 & - & $11.53 \%$ & - & - & - \\
\hline Lipe 87/21/09 & - & $1.16 \%$ & - & $1.42 \%$ & - \\
\hline Lipe 86/20/09 & $20.00 \%$ & $12.50 \%$ & $77.58 \%$ & $20.71 \%$ & $80.00 \%$ \\
\hline Lipe 85/19/09 & $2.70 \%$ & $4.76 \%$ & $19.04 \%$ & $1.96 \%$ & $11.11 \%$ \\
\hline Lipe 84/18/09 & $45.71 \%$ & $9.70 \%$ & $84.87 \%$ & $2.71 \%$ & $7.93 \%$ \\
\hline Lipe 83/17/09 & $4.14 \%$ & $2.79 \%$ & $15.78 \%$ & $3.53 \%$ & - \\
\hline Lipe 81/15/09 & $7.75 \%$ & $6.48 \%$ & $19.02 \%$ & $9.49 \%$ & $59.57 \%$ \\
\hline Lipe 80/14/09 & $1.37 \%$ & $0.86 \%$ & $42.46 \%$ & - & $20.83 \%$ \\
\hline Lipe 79/13/09 & $18.67 \%$ & $14.47 \%$ & $34.15 \%$ & $0.77 \%$ & $45.17 \%$ \\
\hline Lipe 78//12/09 & $0.16 \%$ & $0.54 \%$ & $34.96 \%$ & - & $15.31 \%$ \\
\hline Lipe 76/10/09 & $1.07 \%$ & - & $14.63 \%$ & $2.22 \%$ & $0.74 \%$ \\
\hline Lipe 75/9/09 & - & $1.56 \%$ & $15.28 \%$ & $11.61 \%$ & $22.59 \%$ \\
\hline Sękówka 27/7/12 & - & $13.86 \%$ & $79.54 \%$ & - & $48.83 \%$ \\
\hline Sękówka 17/4/12 & - & - & $100.00 \%$ & $1.27 \%$ & $20 \%$ \\
\hline Sękówka 16/3/13 & - & - & $22.22 \%$ & $1.85 \%$ & $4.54 \%$ \\
\hline Sękówka 15/2/12 & $4.67 \%$ & $8.43 \%$ & $23.33 \%$ & $6.66 \%$ & $55.75 \%$ \\
\hline Sękówka 14/1/12 & $3.70 \%$ & $11.11 \%$ & - & - & $44.44 \%$ \\
\hline Olecka 108/25/09 & $2.53 \%$ & $2.61 \%$ & $1.58 \%$ & - & $2.56 \%$ \\
\hline Olecka 110/27/09 & $4.10 \%$ & - & - & - & - \\
\hline Stradomka 43/47/06 & $1.93 \%$ & $23.52 \%$ & $0.97 \%$ & $0.62 \%$ & $70 \%$ \\
\hline Stradomka 96/66/09 & $6.25 \%$ & $19.23 \%$ & $9.23 \%$ & - & $13.84 \%$ \\
\hline Stradomka 101/71/09 & $9.67 \%$ & $1.93 \%$ & $2.56 \%$ & $2.70 \%$ & $1.51 \%$ \\
\hline
\end{tabular}


not be considered representative, because the total number representing the analysed taxonomic group in this sample amounted to just a few foraminiferal tests. From just a few to $80 \%$ of Reophax tests contained tourmaline particles; on average, one specimen out of three was tourmaline bearing. Considerably lower indicators characterise the tests of Bathysiphon and Nothia - only a few percent of which contain tourmaline grains, however, in exceptional cases the proportion of the tourmaline-bearing tests may reach even a half of the specimens (Table 2). Paratrochamminoides or Trochamminoides are relatively common in the analysed assemblages, but their tests contain tourmaline particles rarely, from a few to a dozen \% per the assemblage. A similar situation was observed in the Recurvoides tests, which, being common and numerous components of each assemblage, seldom contain tourmaline grains, i.e. in only a few percent of the specimens (Table 2).

\section{DISCUSSION}

The Hieroglyphic Beds and the associated Green Shales originated in a deep-marine basin. They are mainly interpreted as turbidites sourced from shallower parts of the basin, however, a considerable influence of hemipelagic-type sedimentation is likely with regards to the thick mudstone-claystone intervals and packages of Green Shales. Except for the uppermost part of their succession, the Hieroglyphic Beds and the Green Shales were deposited below the CCD, which is a limiting factor for the preservation and deposition of the carbonate components. Therefore, pelitic facies of the analysed strata consist of allogeneous detritus with quartz predominant and associated with minor proportions of feldspar, muscovite and heavy minerals.

Associations of heavy minerals are variable in the Outer Carpatian flysch successions and represented by zircon, granet, tourmaline, rutile, kyanite and saturolite that occur in similar proportions of a dozen percent each. Andalusite, epidote, apatite, chromite, spinel, sillimanite, brookite and monazite occur in minor proportions (e.g., Tokarski, 1947; Krysowska-Iwaszkiewicz and Unrug, 1967; Winkler and Ślączka, 1992; Grzebyk and Leszczyński, 2006; Salata, 2013 and references therein). Total amounts of heavy minerals recorded in the Carpathian Flysch strata rarely exceed $1 \%$ by volume (Zerndt, 1924; Jaskólski, 1931), usually ranging between 0.4 and $0.001 \%$

Detrital tourmaline occurs in the sedimentary successions of the Outer Carpathians as an accessory mineral. In general, tourmaline originates as a product of magmatic and metamorphic processes and less often under diagenetic conditions. It is a component of granites infiltrated by boron-rich fluids, granitic pegmatites and some metamorphic rocks, e.g. schist and marble (e.g., Henry and Guidotti, 1985; Henry and Dutrow, 1996; Żaba, 2003; Dutrow and Henry, 2011; Hinsberg et al., 2011a, b and references therein). Tourmaline is hard (7-7.5 on the Mohs scale) but brittle, and with poor cleavage. It occurs as elongated prisms with faces often covered with striations parallel to the direction of elongation. Diagnostic for tourmaline crystals is rounded triangular cross-sectional shape. Except for schorl, it counts among rare and very rare minerals (Żaba, 2003). Tourmaline grains observed in the Outer Carpatians sedimentary sucessions are derived from crystalline primary source rocks of the Bohemian Massif, or other uplifted zones of similar composition (Salata, 2013). Next to relatively common schorl, dravite grains are frequent (Salata, 2013).

The texture of the tourmaline grains incorporated in the foraminiferal tests is another point for discussion. Coarse-grained and rounded turmaline grains occur in sand- stone beds and sandstones associated with conglomerates of the Carpathian Flysch successions (Salata, 2013). On the other hand, the analysed tests contained in mudstone beds incorporate only fine tourmaline grains - almost exclusively of medium and coarse silt grade. They are often broken perpendicularly to the long axis, some are corroded, but not rounded/abraded because their original crystal surfaces and edges are preserved. Rounded coarse tourmaline grains in sandstone beds must be either (1) derived from primary source rocks (e.g., igneous) and abraded during transport on land and/or in coastal marine environment, or (2) recycled, i.e. derived from erosion of pre-existing sandstones. On the other hand, there is little reason to consider that angular silt-size tourmaline grains incorporated in the foraminiferal tests embedded in mudstone layers that form the upper intervals of normally graded turbidite rhythms (Bouma sequences), were derived from a source different than the provenance of the detritus that occurs in the underlying sandstone intervals. In addition, green mudstones, which are probably mostly hemipelagic deposits, also contain tests with angular silt-size tourmaline grains. The contrast between well-rounded coarse tourmaline grains and their angular silt-sized counterparts probably reflects the results of experimental work by Kuenen (1960). He has shown that physical abrasion during fluvial transport of sand-sized grains operates as a process modifying the grain shape ("...fluviatile action is insignificant in the abrasion of sand grains after the first rounding of sharp edges..."). Even aeolian abrasion, which is many orders of magnitude more efficient than fluvial "stops at $50 \mu$ ". Furthermore, chemical corrosion durig transport is an important factor that influences grain shape and size modifications. Therefore, physical abrasion of silt-size grains, and such is the prevailing proportion of the tourmaline grains observed in this study, may be discounted. In addition, it must be noted that the rounded triangular shape of crystals seen in cross-section is diagnostic for tourmaline and should not be confused with physical abrasion during transport, especially in case of silt-size crystals. All these arguments imply that both classes of tourmaline grains in the Carpathian Flysh strata, coarse sand-sized as well as silt, may be derived from the same source area. Therefore, well-preserved, and only silt-grade, broken across, crystals observed here could be derived from either the primary source, or recycled.

Quartz grains constitute the most common detrital component of the Carpathian Flysch successions and other basins dominated by turbidite sedimentation. Additionally, quartz displays good physico-chemical parameters; for both these reasons the agglutinated foraminifera utilize quartz grains for accretion of their tests. This results in foramniferal asociations with monomineral, or quasi-monomineral tests where quartz is the only, or predominant detrital component. In the deep-marine environment tourmaline appears to be a relatively common building material, however, it is an accessory detrital component constituting only a dozen percent of all heavy minerals (Salata, 2013). Grains of other heavy minerals are not utilized as an agglutinated constituent, however, they are equally accessible because their proportion in the sediment is similar, and sometimes even higher. The published data indicate that zircon predominates among heavy minerals found in the Hieroglyphic Beds of the Silesian Nappe (Jaskólski, 1931), and it exceeds the proportion of tourmaline by ca. 10\% (KrysowskaIwaszkiewicz and Unrug, 1967). Interestingly, in the material analysed in the course of this study only one foraminiferal test contained a single zircon grain. Therefore, the foraminifera show a clear affinity to specific mineral phases, and in the deep-marine environment of the Flysch Carpathians tourmaline appears to be their preferred choice. 
Other authors observed that some species of agglutinated foraminifera exhibit clear affinities towards specific mineral phases, involving a curious ability to distinguish between individual minerals (e.g., Heron-Allen and Earland, 1912; Heron-Allen, 1915; Murray, 1971; Jorgensen, 1977; Allen et al., 1999; Laca et al., 2002; Kaminski et al., 2008). In case of the material analysed in the course of this study, tourmaline grains are concentrated by selected taxonomic groups, namely Bathysiphon, Nothia, Psammosiphonella, Reophax, Recurvoides, Trochamminoides and Paratrochamminoides (Appendix 1). These foraminifera are considered as cosmopolitan, occur in high mumbers and together constitute a predominant group. To a large degreee they are counted among primitive foraminifera (sensu Hofker, 1972), which construct morphologically simple tests ranging from tubular with a single chamber, to uniserial composed of several chambers arranged in a single row, to coiled made up of several to a dozen chambers. However, the distribution of tourmaline grains is inhomogeneous within individual taxonomic groups (Table 2). Psammosiphonella and Reophax show especially high preference to tourmaline cementation, as the highest proportion of specimens of these groups contains tourmaline grains. On the other hand, Recurvoides, Trochamminoides and Paratrochamminoides, which occur in similar numbers in the assemblage, select tourmaline grains much less often in spite of the fact that, being actively mobile on the surface and within sediment, they have easier access to this test-building detrital component. Also, relatively low proportion of Bathysiphon incorporate tourmaline grains, but they agglutinate inorganic particles and various non-quartz mineral components relatively often (Dick, 1928; Bruce et al., 1981; Gooday nad Claugher, 1989; Gooday et al., 1995b, 2002; Cole and Valentine, 2006).

The size of the grains segregated by specific species is also preferential (e.g., Heron-Allen, 1915; Smith and Kasler, 1970; Gooday nad Claugher, 1989; Allen et al., 1999; Bartholdy et al., 2005). Tourmaline grains typical for flysch sediments represent a relatively large building component of the analysed tests (Figs. 4-6 and 8), which is why their highest proportion occurs in the coarse-grained tests of i.e. Reophax or Psammosiphonella (Table 2 and Appendix 1). Coarse-grained tests of other agglutinated foraminifera also belong to the observed associations; among them are numerous Recurvoides, common Cribrostomoides, Placentammina or irregularly appearing Karrerulina. These taxa also accrete tourmaline into their tests, but much less often than Reophax or Psammosiphonella. Except for the groups Trochamminoides and Paratrochamminoides, the foraminifera agglutinating fine-grained tourmaline in their tests occur less often. However, tourmaline crystals were observed in very fine-grained tests of other taxa, e.g. Ammodiscus cretaceus (Reuss), A. peruvianus Berry, Reticulophragmium amplectens (Grzybowski), Haplophragmoides walteri (Grzybowski) (Table 2 and Appendix 1). On the other hand, in many commonly occurring forms, e.g. Glomospira charoides (Jones et Parker), G. gordialis (Jones et Parker), Haplophragmoides nauticus Kender et al. or Spiroplectammina spectabilis (Grzybowski), tourmaline crystals were not observed as yet. It is possible that the availability of tourmaline grains of the appropriate size in the host sediment may be a limiting factor in such cases.

The most commonly agglutinated are short-columnar crystals or perpendicularly broken fragments of long crystals, which results in "building blocks" equivalent to the geometric parameters of short-column. Long columns are rare and found only in fine-grained tests. Therefore, we observe a clear preference for specific grain shape, not only size. It may be significant that the general outlines of short columns of tourmaline are similar to the agglutinated quartz grains, however, the latter are rather irregular in shape. Interestingly, the size and shape of zircon and apatite grains are similar, and zircon is as common in the Carpathian Flysch as tourmaline (Salata and Uchman, 2013), but only the latter mineral is accreted in the foraminiferal tests.

Considering the trophic strategy of foraminifera analysed from the perspective of morphogroups (after Jones and Charnock, 1985 and later modifications), it appears that the numbers of epifaunal and infaunal forms that agglutinate tourmaline are comparable. Predominant among tourmaline-bearing foraminifera are two morphotypes classified as erect epifauna and tapered elongated infauna. The tubular foraminifera, living in vertical position and feeding on nutrients captured from suspension, represent erect epifauna (e.g., Psammosiphonella, Rhabdammina). The elongated tapered forms actively move and migrate deep within the sediment as active feeders (e.g., Reophax, Pseudonodosinella). It seems that infauna, which includes mobile foraminifera actively penetrating the bottom sediment, had a better opportunity to access tourmaline grains as the test-building component (Waśkowska and Łodziński, 2011a, b). On the other hand, the distribution of the foraminiferal morphogroups indicates that epifauna had a similar access to tourmaline grains at the sediment surface. Surprisingly large numbers of sedentary erect foraminifera incorporated the highest quantity of tourmaline grains, which must have been accessible within reach of their pseudopodia.

The analysed material points to an interesting relation between the type of the hosting sediment, which results from a specific depositional regime, the numbers of the tourmaline-bearing foraminifera, and the incorporated tourmaline grains. A low proportion, or absence, of tourmaline accreting tests was observed in mudstone-sandstone facies and in turbidite flysch complexes. This refers to the Hieroglyphic Beds in the Lipie section, the lower part of the Sękówka section and various stratigraphic positions in the Stradomka profile (Figs. 2 and 3). However, the number of tourmaline-bearing tests is significantly higher in samples of mudstone-claystone complexes, in green mudstones at Lipie and in the upper part of the Sękówka and Stradomka sections where hemipelagic deposition typified by relatively low sedimentation rate contributed to the accumulation process. Similarly, the tourmaline-bearing tests occur in the foraminiferal assemblages found in the variegated mudstones developed as green clayey mudstones interlaminated with cherry-red claystones. Also, the taxonomic variety of the analysed assemblages considerably increases in variegated shales, which reflects conditions ecologically favourable for development of the benthic fauna.

Samples of clayey mudstones deposited in the deep-marine environment strongly influenced by hemipelagic sedimentation contain the highest numbers of agglutinated tourmaline grains because the foraminiferal tests embedded in such sediments concentrated them. Detrital tourmaline is an accessory component of the Carpathian sedimentary rocks in which its frequency amounts to ca. $0.15 \%$. These mudstones contain a low proportion of fine psammitic and coarse psefitic fractions $(0.08-0.03 \mathrm{~mm})$ therefore the forms predisposed to accretion of coarse-grained tests show high activity in search of building material. The necessary detrital material was supplied not only by sediment gravity flows but also because of the activity of infauna. The Hieroglyphic Beds and green shales are intensely bioturbated. Therefore, mobility of other organisms within the sediment may have resulted in mixing and overturning of the detrital material. The presence of heavy minerals in the foraminiferal tests is unrelated to their concentration in the surrounding sediment, which was also noticed in the Recent environments (Makled and Langer, 2009). 
The analyses presented here are focused on the foraminifera from the Eocene strata of the Silesian Nappe. However, numerous specimens of tourmaline-agglutinating foraminifera are also noted in the Eocene-age Hieroglyphic Beds of the Skole Nappe, as well as in the Łabowa Shale Formation, Beloveza Formation and Zembrzyce Member of the Maków (Magura) Formation in the Magura Nappe (Waśkowska and Łodziński, 2011a, b). Most of these lithostratigraphic units originated in the depositional regime similar to that prevailing in the neighbouring Silesian Basin.

\section{CONCLUSIONS}

Next to quartz, tourmaline is the detrital component commonly incorporated in tests of the Eocene age deep-marine foraminifera of the Carpathian Basin. These tourmaline grains are usually fragments of automorphic long columnar crystals that bear traces of abrasion that probably occurred during fluvial transport in the source area, as well as chemical corrosion. They constitute allochthonous detritus transported from shallower parts of the basin by turbidity currents. On average, tourmaline grains are 39-69 $\mu \mathrm{m}$ long and 10-30 $\mu \mathrm{m}$ wide, which results in short columnar "building blocks". A relatively rare variety of tourmaline - dravite - predominates, whereas shorl is rare. The observed foraminifera incorporated between one and several tourmaline grains per test. The number of tourmaline-bearing tests usually amounts to a maximum of several percent per assemblage, but in extreme case reaches $29 \%$.

The distinct preference of the foraminifera for selecting tourmaline for their tests remains in radical contrast with the marginal contribution of this accessory mineral to the host rock composition. The organisms do not utilise grains of other heavy minerals even if their size and shape are comparable with tourmaline grains.

Tourmaline grains were observed in the tests of 37 species of the foraminifera that belong to 20 genera. These mineral grains occur most commonly in simple forms characterized by rather uncomplicated structure and represented by the cosmopolitan organisms agglutinating coarse-grained tests. The size of tourmaline clasts corresponds to the average diameter of test-building grains, and they occur in the fine-grained tests least frequently. Psammosiphonella and Reophax show the highest affinity to incorporate tourmaline, while Bathysiphon and Nothia are less selective in this respect. It is interesting that Psammosiphonella, the erect epifaunal form, displays preference to include tourmaline grains in its test, however, its mobility is very limited which should be critically limiting its ability in accessing tourmaline grains scattered within the surrounding sediment.

The highest quantity of tourmaline-bearing forms occurs in the assemblages of benthic foraminifera, which show diversified taxonomic composition and complex trophic structure, and lived in favourable eological conditions. The tourmaline-bearing forms are concentrated in highly bioturbated mudstone-claystone complexes of green and variegated mustones within the Hieroglyphic Beds. Tourmaline grains buried in the sediment could have been shifted due to the activity of bioturbating organisms, which might have increased the chance of them being found by the tourmaline agglutinating foraminifera.

Acknowledgements. The author is grateful to M. Łodziński $(A G H), M$. Wendorff (AGH) for helpful discussions of several problems related to this research. T. Wójcik helped with laboratory work. R. Stadnik (AGH), M. Czuj-Górniak (AGH), E. Waśkowska, K. Oliwa (SP 34) and P. Warmuz offered their support in field work. D. Peryt (PAN), M. Cieszkowski (UJ) and M.A. Kaminski (KFUPM) kindly reviewed the manuscript. SEM and EDS analyses were done and pictures taken at the Scanning Microscopy Laboratory WGGiOS AGH in Kraków. Microprobe analytical work was conducted at Inter-Institute Analytical Complex for Minerals and Synthetic Substances of the Warsaw University. This research was financially supported by AGH University of Science and Technology in Krakow grant no. 11.11.140.173.

\section{REFERENCES}

Allen, K., Roberts, S., Murray, J.W., 1999. Marginal marine agglutinated foraminifera: affinities for mineral phases. Journal of Micropalaeontology, 18: 183-191.

Bartholdy, J., Leipe, T., Frenzel, P., Tauber, F., Bahlo, R., 2005. High resolution Single Particle Analysis by scanning electron microscopy: a new tool to investigate the mineral composition of agglutinated foraminifers. Studia Geologica Polonica, 124: 53-65.

Bender, H., Hemleben, C., 1988. Constructional aspects in test formation of some agglutinated foraminifera. Abhandlungen der Geologischen Bundesanstalt, 41: 13-21.

Bruce, H., Corliss, B.H., Milliman, J.D., 1981. The use of phillipsite in test construction of agglutinated deep-sea benthonic foraminifera. Sedimentology, 28: 401-406.

Burtan, J., 1972. Szczegółowa mapa geologiczna Polski, 1:50 000, arkusz Wisła (in Polish). Wyd. Geol., Warszawa.

Burtan, J., 1974. Szczegółowa mapa geologiczna Polski, 1: 50000 , arkusz Mszana Dolna (in Polish). Wyd. Geol., Warszawa.

Burtan, J., 1978. Objaśnienia do Szczegółowej mapy geologicznej Polski, 1: 50 000, arkusz Mszana Dolna (in Polish). Wyd. Geol., Warszawa.
Burtan, J., Sokołowski, S., Sikora, W., Żytko, K., 1956. Szczegółowa mapa geologiczna Polski 1: 50 000, arkusz Milówka (in Polish). Wyd. Geol., Warszawa.

Cartwright, N.G., Gooday, A.J., Jones, A.R., 1989. The morphology, internal organization, and taxonomic position of Rhizammina algaeformis Brady, a large, agglutinated, deep-sea foraminifer. Journal of Foraminiferal Research, 19: 115-125.

Chodyń, R., Waśkowska-Oliwa, A., 2006. Lithostratigraphy and biostratigraphy of the Paleocene-Early Oligocene flysch sediments in the western part of the Szczyrzyc Synklinorium, Silesian Nappe (Polish Outer Carpathians). Scientific Annals of the School of Geology, Aristole University of Thessaloniki, Belgrade, Serbia, Special Volume, 100: 57-60.

Cieszkowski, M., 1992. Michalczowa zone: a new unit of Fore-Magura zone, Outer Carpathians, South Poland (in Polish with English summary). Geologia,18: 1-125.

Cieszkowski, M., Koszarski, A., Leszczyński, S., Michalik, M., Radomski, A., Szulc, L., 1991. Szczegółowa mapa geologiczna Polski, 1: 50 000, arkusz Ciężkowice (in Polish). Państwowy Instytut Geologiczny, Warszawa. 
Cole, K.E., Valentine, A.M., 2006. Titanium biomaterials: titania needles in the test of the foraminiferan Bathysiphon argenteus. Dalton Transactions, 3: 430-432.

Commeau, R.F., Reynolds, L.A., Poag, C.W., 1985. Elemental X-ray mapping of agglutinated foraminifer tests: A nondestructive technique for determining compositional characteristics. Micropaleontology, 31: 380-386.

Dick, A.B., 1928. On needles of rutile in the test of Bathysiphon argenteus. Edinburgh Geological Society Transactions, 12 19-21.

Dutrow, B.L., Henry, D.J., 2011. Tourmaline: a geologic DVD. Elements, 7: 301-306.

Golonka, J., Gahagan, L., Krobicki, M., Marko, F., Oszczypko, N., Ślączka, A., 2006. Plate tectonic evolution and paleogeography of the Circum-Carpathian Region. AAPG Memoir, 84: 11-46.

Golonka, J., Waśkowska-Oliwa, A., 2007. Stratigraphy of the Polish Flysch Carpathians between Bielsko-Biała and Nowy Targ (in Polish with English summary). Geologia, 33: 5-28.

Golonka, J., Krobicki, M., Waśkowska-Oliwa, A., Vašíček, Z., Skupien, P., 2008. Main paleogeographical elements of the West Outer Carpathians during Late Jurassic and Early Cretaceous times (in Polish with English summary). Geologia, 34: 61-72

Golonka, J., Ślączka, A., Waśkowska, A., Krobicki, M., Cieszkowski, M., 2013. Budowa geologiczna zachodniej części polskich Karpat zewnętrznych (in Polish). In: Głębokomorska sedymentacja fliszowa - sedymentologiczne aspekty historii basenów karpackich (eds. M. Krobicki and A. Feldman-Olszewska): 11-62. V Polska konferencja Sedymentologiczna. Państwowy Instytut Geologiczny Państwowy Instytut Badawczy, Warszawa.

Gooday, A.J., Claugher, D., 1989. The genus Bathysiphon (Protista, Foraminiferida) in the northeast Atlantic: SEM observations on the wall structure of seven species. Journal of Natural History, 23: 591-611.

Gooday, A.J., Smart, C.W., 2000. Wall structure and test morphology in three large deep sea agglutinated foraminifera, Rhabdammina parabyssorum Stschedrina 1952, R. abyssorum Sars 1869 and Astrorhiza granulosa (Brady 1879) (Foraminiferida, Textulariina). Grzybowski Foundation Special Publication, 7: 105-115.

Gooday, A.J., Bernhard, J.M., Bowser, S.S., 1995a. The taxonomy and ecology of Crithionina delacai sp. nov., and abundant large agglutinated foraminifer from Explorers Cove, Antarctica. Journal of Foraminiferal Research, 25: 290-289.

Gooday, A.J., Nott, J.A., Davis, S., Mann, S., 1995b. Apatite particles in the test wall of the large agglutinated foraminifer Bathysiphon major (Protista). Journal of the Marine Biological Association of the UK, 75: 469-481.

Gooday, A.J., Pond, D.W., Bowser, S.S., 2002. Ecology and nutrition of the large agglutinated foraminiferan Bathysiphon capillare in the bathyal NE Atlantic: distribution within the sediment profile and lipid biomarker composition. Marine Ecology Progress Series, 245: 69-82.

Gooday, A.J., Uematsu, K., Kitazato, H., Toyofuku, T., Young, J.M., 2010. Traces of dissolved particles, including coccoliths, in the tests of agglutinated foraminifera from the Challenger Deep (10,897 m water depth, western equatorial Pacific). Deep Sea Research Part I: Oceanographic Research Papers, 57: 239-247.

Grzebyk, J., Leszczyński, S., 2006. New data on heavy minerals from the Upper Cretaceous-Paleogene flysch of the Beskid Śląski Mts. (Polish Carpathians). Geological Quarterly, 50 (2): 265-280.

Hemleben, C., Kaminski, M.A., 1991. Agglutinated foraminifera: an introduction. In: Paleoecology, Biostratigraphy, Paleoceanography and Taxonomy of Agglutinated Foraminifera (eds. C Hemleben, M.A. Kaminski, W. Kuhnt and D.B. Scott): 3-11. Kluwer Academic/Springer, Dordrecht.
Henry, D.J., Dutrow, B.L., 1996. Metamorphic tourmaline and its petrologic applications. Reviews in Mineralogy, 33: 503-557.

Henry, D.J., Guidotti, C.V., 1985. Tourmaline as a petrogenetic indicator mineral: an example from the staurolite-grade metapelites of NW Maine. American Mineralogist, 70: 1-15.

Heron-Allen, E., 1915. A short statement upon the theory, and the phenomena of purpose and intelligence exhibited by the protozoa, as illustrated by selection and behaviour in the Foraminifera. Journal of the Royal Microscopical Society, 6: 547-557.

Heron-Allen, E., Earland, A., 1912. On some foraminifera from the North Sea, etc., dredged by the fisheries cruiser 'Goldseeker' (International North Sea Investigations - Scotland). I. On some new Astrorhizidae and their shell-structure. Journal of the Royal Microscopical Society, 32: 382-389

Hess, S., Kuhnt, W., Spivey, B., Kaminski, M.A., Whittaker, J.E., 2000. Ash grains of the $1991 \mathrm{Mt}$. Pinatubo eruption as a tracer in rose Bengal stained deep sea agglutinated foarminifera: how old is Freddy? Grzybowski Foundation Special Publication, 7: 126.

Hinsberg, V.J., van, Henry, D.J., Dutrow, B.L., 2011a. Tourmaline as a petrologic forensic mineral: a unique recorder of its geologic past. Elements, 7: 327-332.

Hinsberg, V.J., van, Henry, D.J., Marschall, H.R., 2011b. Tourmaline: an ideal indicator of its host environment. Canadian Mineralogist, 49: 1-16.

Hofker, J.F., 1972. Primitive agglutinated foraminifera. Brill, Netherlands.

Höfling, R.F., 1988. An agglutinated foraminifera association from a Santonian hippuritid patchreef-lagoon (Austria). Abhandlungen der Geologischen Bundesanstalt, 41: 133-141.

Jaskólski, S., 1931. Contributions to the geology and petrography of the Carpathian Flysch in the victinity of Rymanów (in Polish with English summary). Sprawozdania Polskiego Instytutu Geologicznego, 6: 697-741.

Jones, R.W., Charnock, M.A., 1985. "Morphogrups" of agglutinated Foraminifera, their life positions and feeding habitas and potential applicability in (paleo)ecological studies. Revue de Paleobiologie, 4: 311-320.

Jorgensen, N.O., 1977. Wall structure of some arenaceous foraminifera from the Maastrichtian white chalk (Denmark). Journal of Foraminiferal Research, 7: 313-321.

Kaminski, M.A, Gradstein, F.M., 2005. Atlas of Paleogene cosmopolitan deep-water agglutinated foraminifera. Grzybowski Foundation Special Publication, 10: 1-548.

Kaminski, M.A., Armitage, D.A., Jones, A.P., Coccioni, R., 2008. Shocked diamonds in agglutinated foraminifera from the Cretaceous/Paleogene Boundary, Italy - a preliminary report. Grzybowski Foundation Special Publication, 13: 57-61.

Krysowska-Iwaszkiewicz, M., Unrug, R., 1967. Heavy mineral in the flysch of the Polish Western Carpathians. Bulletin of the Polish Academy of Sciences, Earth Sciences, 15: 57-64.

Książkiewicz, M., ed., 1962. Atlas geologiczny Polski. Zagadnienia stratygraficzo-facjalne.Kreda i starszy trzeciorzęd polskich Karpatach zewnetrznych (in Polish). Wyd. Geol., Warszawa.

Książkiewicz, M., 1972. Budowa geologiczna Polski. Tom 4, Tektonika. Część 3, Karpaty (in Polish). Wyd. Geol., Warszawa.

Książkiewicz, M., 1977. The tectonics of the Carpathians. In: Geology of Poland, Volume IV, Tectonics (ed. W. Pożarski): 476-620. Wyd. Geol., Warszawa.

Kuenen, P.H., 1960. Experimental abrasion. 4. Eolian action. Journal of Geolology, 68: 427-449.

Laca, T.E., de, Bernhard, J.M., Reilly, A.A., Bowser, S.S., 2002. Notodendrodes hyalinosphaira (sp. nov.): structure and autecology of an allogromiid-like agglutinated foraminifer. Journal of Foraminiferal Research, 32: 177-187.

Leszczyński, S., Radomski, A., 1994. Objaśnienia do Szczegółowej mapy geologicznej Polski, 1: 50 000, arkusz Ciężkowice (in Polish). Wyd. Geol., Warszawa.

Łuczkowska, E., 1993. Mikropaleontologia (in Polish). Protozoa. Wydawnictwa AGH, Kraków. 
Makled, W.A., Langer, M.R., 2009. Preferential selection of titanium-bearing minerals in agglutinated Foarminifera: IImenite $\left(\mathrm{FeTiO}_{3}\right)$ in Textularia hauerii d'Orbigny from the Bazaruto Archipelago, Mozambique. Revue de Micropaleontologie, 53 163-173.

Mancin, N., Basso, E., Pirini, C., Kaminski, M. A., 2012. Selective mineral composition, functional test morphology and paleoecology of the agglutinated foraminiferal genus Colominella Popescu, 1998 in the Mediterranean Pliocene (Liguria, Italy). Geologica Carpathica, 63: 491-502.

Murray, J.W., 1971. An Atlas of British Recent Foraminiferids. American Elsevier, New York.

Murray, J.W., 1973. Wall structure of some agglutinated Foraminiferida. Palaeontology, 16: 777-786.

Podobina, V.M., Tatyanin, G.M., 2000. Morphology, wall composition and evolution of the Haplophragmoididae (agglutinated foraminifera). Grzybowski Foundation Special Publication, 7 397-401.

Salata, D., 2013. Source rocks for heavy minerals in lower part of Menilite Formation of Skole Nappe (Polish Flysch Carpathians) based on study of detrital garnet and tourmaline. Annales Societatis Geologorum Poloniae, 83: 1-17.

Salata, D., Uchman, A., 2013. Conventional and high-resolution heavy mineral analyses applied to flysch deposits: comparative provenance studies of the Ropianka (Upper Cretaceous-Paleocene) and Menilite (Oligocene) formations (Skole Nappe, Polish Carpathians). Geological Quarterly, 57 (4): 649-664.

Smith, M.A., Kaesler, R.L., 1970. Selection of adventitious test material by Reophax curtus (Foraminiferida). Journal of Paleontology, 44: 953-957.

Switzer, G., Boucot, A.J., 1955. The mineral composition of the some microfossils. Journal of Paleontology, 29: 525-533.

Szymakowska, F., 1979. Geology of the southern limb of the Gorlice fold between Gorlice and Kryg (Polish Middle Carpathians) (in Polish with English summary). Rocznik Polskiego Towarzystwa Geologicznego, 49: 85-103.

Ślączka, A., Kaminski, M.A., 1998. A guidebook to excursions in the Polish Flysch Carpathians. Grzybowski Foundation Special Publication, 6: 1-171.

Ślączka, A., Kruglow, S., Golonka, J., Oszczypko, N., Popadyuk, I., 2006. The general geology of the Outer Carpathians, Poland, Slovakia, and Ukraine. AAPG Memoir, 84: 221-258.
Tendal, O.S., Swinbanks, D.D., Shirayama, Y., 1982. A new fauna xenophyophore (Xenophyophorea, Protozoa) with notes on its ecology and possible trace fossil analogues. Oceanologica Acta, 5: 325-329.

Thomsen, E., Rasmussen, T.L., 2008. Coccolith-agglutinating foraminifera from the early Cretaceous and how they constructed their tests. Journal of Foraminiferal Research, 38-39: 193-214.

Tokarski, J., 1947. Ciężkie minerały jako wskaźniki stratygraficzne serii fliszowych (in Polish). Nafta, 3: 261-264.

Unrug, R., 1979. Palinspastic reconstruction of the Carpathian arc before the Noegene tectogenesis. Rocznik Polskiego Towarzystwa Geologicznego, 49: 1-21.

Waśkowska, A., Łodziński, M., 2011a. Tourmalines in the tests of deep water agglutinated Reophax pilulifer Brady - preliminary results. Grzybowski Foundation Special Publication, 17: 138-139.

Waśkowska, A., Łodziński, M., 2011b. Turmaliny jako komponent ścian skorupek głębokowodnych otwornic aglutynujących gatunku Reophax pilulifer Brady - badania wstępne na bazie eoceńskiego materiału z Karpat Zewnętrznych (in Polish). In: 12 Czech-Slovak-Polish Paleontological Conference. Abstract Book (ed. D. Boorova): 105-106. Bratislava.

Weston, J.F., 1984. Wall structure of the agglutinated foraminifera Eggerella bradyi (Cushman) and Karreriella bradyi (Cushman). Journal of Micropalaeontology, 3: 29-31.

Winkler, W., Ślączka, A., 1992. Sediment dispersal and provenance in the Silesian, Dukla and Magura flysch nappes (Outer Carpathians, Poland). Geologische Rundschau, 81: 371-382.

Zerndt, J., 1924. Petrographische Studien fiber Karpathen-Sandstein der Umgegend von Ciezkowice. Bulletin International de l'Academie Polonaise des Sciences et des Lettres, Serie A, 5-6: 195-218.

Żaba, J., 2003. Ilustrowany słownik skał i minerałów (in Polish). Videograf II. Katowice.

Żytko, K., Gucik, S., Oszczypko, N., Zając, R., Garlicka, I., Nemčok, J., Eliaš, M., Menčik, E., Dworak, J., Stranik, Z., Rakuš, M., Matejovska, O., 1989. Geological map of the Western Outer Carpathians and their foreland without Quaternary formations. In: Geological Atlas of the Western Carpathians and their Foreland (eds. D. Poprawa and J. Nemčok). Państwowy Instytut Geologiczny, Warszawa. 